\title{
Application of Remote Sensing, Geology And Geomorphological Studies For Mass Wasting Zone Analysis In Jotiba- Panhala Hill Range Area, Kolhapur District, Maharashtra, India
}

\author{
Gurav Chandrakant ${ }^{1}$, Babar Md. ${ }^{1}$, Patil Yogita ${ }^{2}$, Patil Abhijit ${ }^{3}$ and Patode H.S. ${ }^{4}$ \\ 1. Department of Geology, Dnyanopasak College, Parbhani-431 401 M.S., India \\ 2. Department of Geology, Gopal Krishan Gokhale College, Kolhapur-M.S. India \\ 3. Department of Geology, Vivekanand College, Kolhapur-416 003 M.S. India \\ 4. School of Earth Science, SRTM University, Nanded-431606 M.S. India
}

\begin{abstract}
Jotiba-Panhala hill range trending east-west and play a vital role as a water divider between Panchaganga and Varna rivers sub-basins in Kolhapur district, Maharashtra. For present research 483.7 sq. $\mathrm{km}$. area is selected for mass wasting zonation analysis. The highest elevation in area is 991 meters and the lowest is 533 meters. The drainage pattern observed is dendritic to sub dendritic. Most of the area shows high drainage density and stream frequency indicating the area is low permeability in nature. Geologically, study area belongs to Deccan Volcanic Province (DVP) of Upper Cretaceous to Lowe Eocene age. On the top of the hill laterite rock is formed due to in situ chemical weathering of basalt. It is of late Pleistocene age. Lithostratigraphically, study area is belongs to Mahableshwar formation of Upper Deccan Traps. In present study, Remote sensing and Geographical Information System (GIS) techniques are used with the help of Resourcesat1, LISS-III, 24 m., satellite image January 2013 (Downloaded from Bhuvan), SRTM DEM-1-arc 30 meter resolution (Downloaded from USGS) and SOI toposheets on 1:50000 scale with adequate ground truth in ArcGIS 10.1 and ERDAS 2014 software. In the present research, it is found that weathered parts of lava flows, regoliths and talus deposits, during rainy season due to heavy rainfall in short period of time lose their strength and landslides occurs. High rainfall generally is the main cause of landslides. Some other causes are terrain factors such as slope, lithology, geological structures, land use/ land cover and geomorphology of the area. Finally Landslide susceptible zone map is developed for planning, development and risk management.
\end{abstract}

Key Words: Landslide, Mass wasting, Morphometry, Jotiba-Panhala hill

\section{Introduction}

Landslide is the movement mass of rocks, earth or debris down the slope [1]. In 1978 Varnes [2] classified Landslide in two types based on the type of movement (fall) and type of material (rock). Landslide susceptibility is defined as a quantitative or qualitative assessment of the classification, volume (or area) and spatial distribution of landslides, which exists or potentially may, occurs in an area. Now days Remote Sensing and Geographical Information System (GIS) techniques are used for landslide zones mapping [3,4]. In India, landslide disasters commonly occurs in hilly area due to heavy rain fall particularly in Himalayan area, but year 2014, 30 July Malin village, Ambegaon taluka in Pune district, Maharashtra. The landslide which is hit early in the morning residents were asleep, was believed to have been caused by a bust of heavy rainfall and kill 135 peoples [5]. Hence Landslide Susceptible zonation mapping is also an important aspect in Western Ghats Belt (WGB) for development, planning and risk management study. The present study area is also a small part of WGB, on the basis of mass wasting evidences we try to analyse the maximum possible landslide zone in JotibaPanhala hill range area in Kolhapur district.

\section{Study Area}

The Jotiba-Panhala hill range trending east-west, falls within the latitude $16^{0} 42^{\prime} 15.1^{\prime \prime} \mathrm{N}$ to $16^{0} 55^{\prime} 6.5^{\prime \prime}$ $\mathrm{N}$ and longitude $73^{\circ} 54^{\prime} 12.3^{\prime \prime} \mathrm{E}$ to $74^{\circ} 20^{\prime} 42.0^{\prime \prime} \mathrm{E}$ in Survey of India (SOI) toposheet numbers $47 \mathrm{H} / 13,47 \mathrm{~L} / 1$, $47 \mathrm{~L} / 2,47 \mathrm{~L} / 5$, and $47 \mathrm{~L} / 6$ on the scale $1: 50000$ and geographically this hill is placed in SW fringe of Maharashtra. It is occupies area of about 483.7 Sq. km. in Panhala taluka in Kolhapur district of Maharashtra. Jotiba hill is also known as Wadi-Ratnagiri and it is famous for Jotiba temple. Similarly, Panhala hill is famous tourist spot for Panhala fort. This hill range is major water divider between Varna and Panchaganga Rivers. Varna River is in north side and Panchaganga River is in south side of this hill range. The minimum and maximum temperature is $19^{\circ}$ to $40^{\circ}$ averages are $27^{\circ}$, average rainfall is $1899 \mathrm{~mm}$ and humidity is $55 \%$. 


\section{Methodology}

The study comprises mainly field visit and laboratory study. Field survey is carrying out for study the geology and geomorphological setup of the area. After field work, laboratory study was carried with the help of Survey of India topographic maps on 1:50000 scale, SRTM DEM $30 \mathrm{~m}$. resolution (Downloaded by USGS), and Resoursat-1 IRS LISS-III satellite image $24 \mathrm{~m}$. resolution (Downloaded by Bhuvan). Resoursat-1 IRS LISSIII- 24 m. satellite image processed under ERDAS 10.4 software for stacking the bands R-3, G-2, and B-1.

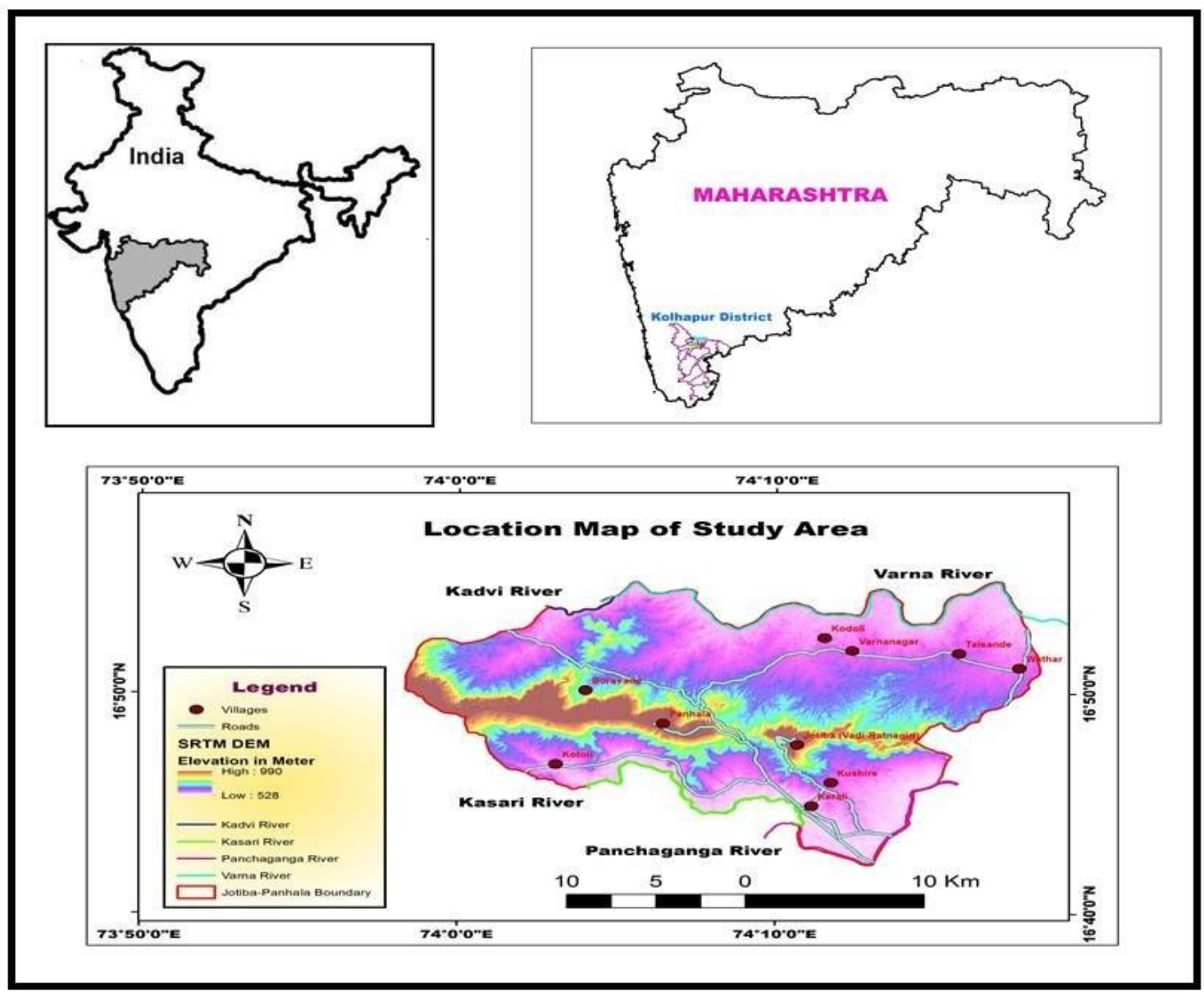

Fig. 1 Location Map of Jotiba- Panhala hill range area

In present study, ArcGIS 10.1 and ERDAS 10.4 software is used for data generation and creation of maps. The base map i.e. location map (Fig.1) and drainage map (Fig.2) are prepared with the help of topographic map and ArcGIS 10.1 software. The method for stream ordering is adapted from Strahler [6]. The slope map (Fig.8) is prepared through SRTM DEM of $30 \mathrm{~m}$. resolution in percentage scale using ArcGIS 10.1 software. The Satellite imagery Resoursat-1 IRS LISS-III was visually interpreted by using slandered interpretation key such as tone, colour, texture, pattern of drainage, shape and topography etc. to prepare geomorphological map (Fig.4) Land use/ Land cover map (Fig. 7) and Landslide zonation mapping (Fig. 9). Finally conventional information such as geology, geomorphology and land use/ land cover change characteristics collected during field checks were used in the final conclusions of the present study.

\section{Morphometric Analysis}

The study area generally shows well developed dendritic to sub-dendritic drainage pattern. Dendritic and sub dendritic drainage pattern are governed by regional slope, homogeneous lithology and relief [7]. On the basis of morphometric analysis of Jotiba-Panhala hill range found that, the streams originating from this hill are $1^{\text {st }}$ to $5^{\text {th }}$ ordered [6]. The whole area contains 1667 streams and the total length of all the streams is $1236.65 \mathrm{~km}$. The average bifurcation ratio [8] is 3.99. The bifurcation ratio of the area is indicating that the homogeneous sub-surface lithology and drainage of this area is not disturbed due to tectonic activity. The drainage density is $2.56 \mathrm{~km} / \mathrm{km}^{2}$ [9], stream frequency is 3.45 streams $/ \mathrm{km}^{2}$ [9], and textural ratio [10]. The high drainage density and high stream frequency indicates that the rapid runoff and impermeable lithology. The textural ratio is 13.35 $\mathrm{km}^{-1}$ shows that the drainage is very fine texture [11]. 


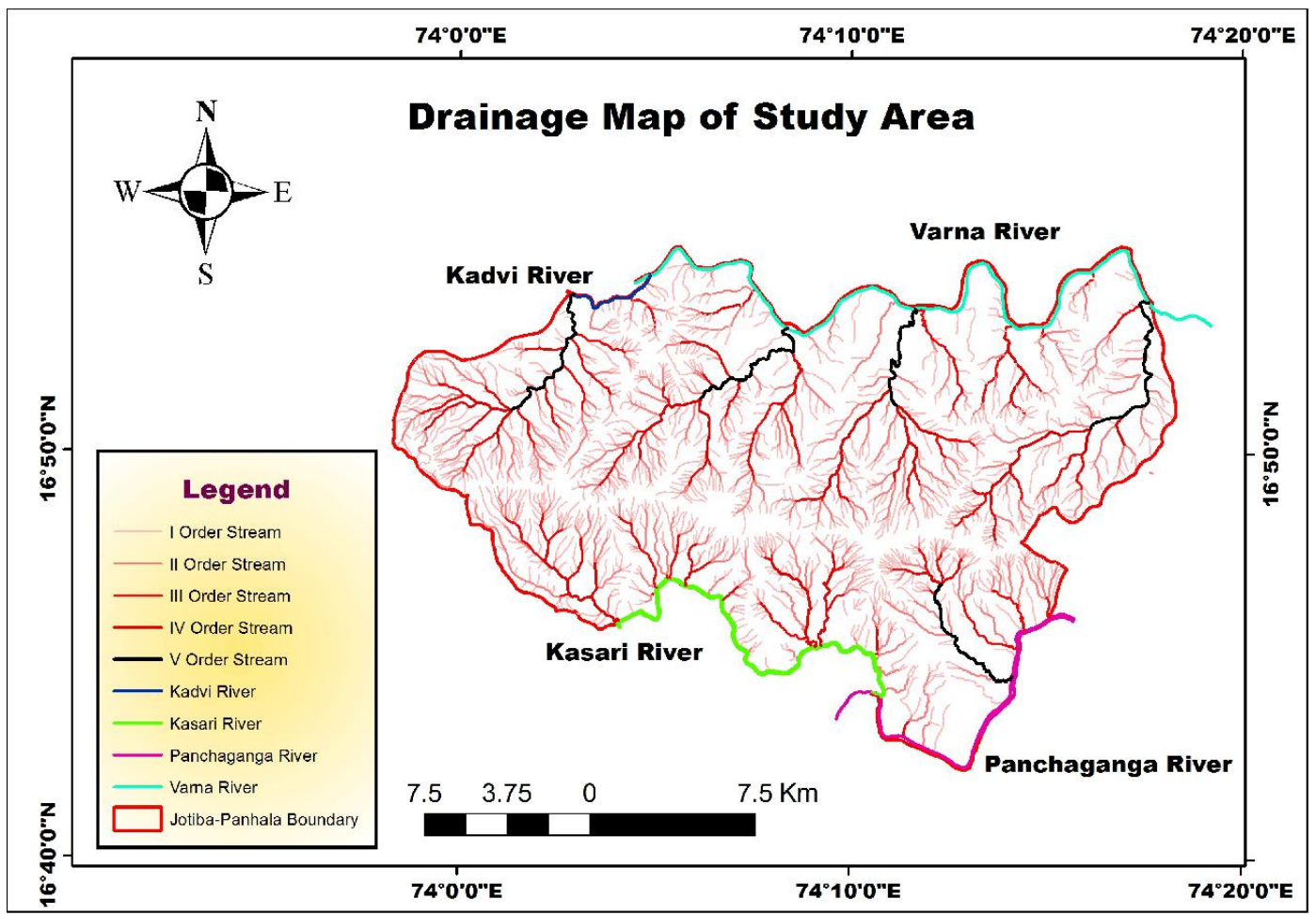

Fig. 2 Drainage Map of Jotiba- Panhala hill range area

\section{Geology of the Area}

The Deccan volcanic province (DVP) is one of the largest horizontally disposed continental flood basalt (CFB) provinces in the world. It is cover an area of about 500,000 sq. km. in western and central parts of the peninsular India. Geologically, present study area is totally covered by Deccan Volcanic Basaltic (DVB) lava flows of Upper Cretaceous to Lower Eocene age. In the study area, Geological mapping is already done by Geological Survey of India (GSI) [12,13,14].

Geological field work has been carried out with the help of previous GSI report [15]. On this basis, it is observed that several 'aa' type lava flows are at some places separated by red bole beds (Tachylitic bands). There are two types of basalt are observed, one is compact basalt ('aa' type) and another is vesicularamygdaloidal basalt (compound pahoehoe type). The vesicular amygdaloidal basalt (Compound Pahoehoe) flows are formed by the outpouring of comparatively viscous lava in small quantities through a large number of outlets [16,17]. The aa basalt flow also show the columnar joints (Fig. 3).

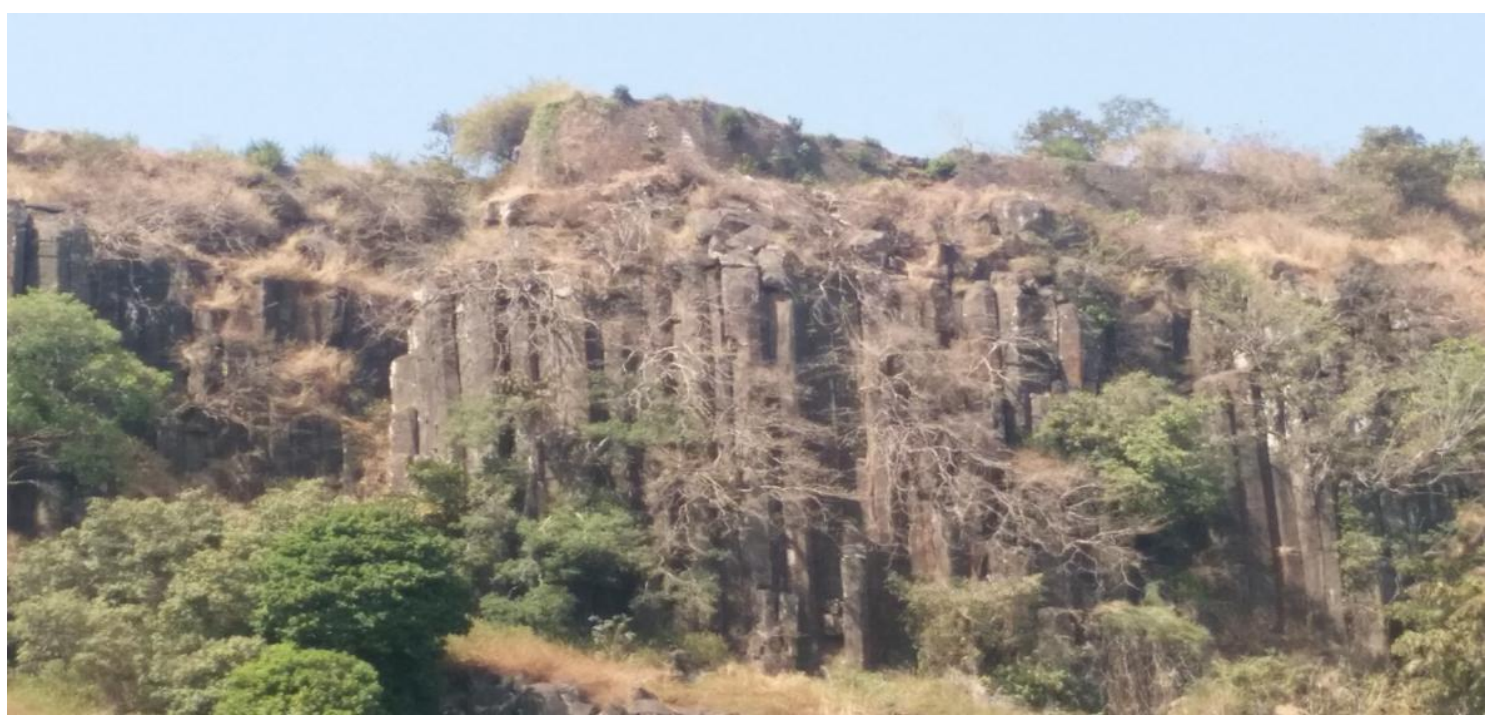

Fig. 3 Columnar Joints in Basalt at Panhala Fort, Kolhapur District. 
Basalt is black coloured, ultramafic, basic, volcanic, igneous rock mainly composed of augite, calcicplagioclase and iron oxide. Jointing pattern of Basalt is mainly vertical or horizontal. Basalt also shows spheroidal weathering due to high temperature and high rainfall. During rainy season due to heavy rainfall water percolates under vertical and horizontal joints in basaltic formations. After sometimes it comes out in the form of natural spring in between two Basaltic lava formations. If these springs are comes out in the high relief and steep slope area into weathered lava formation or talus deposits rolling down from the hill, Landslides are occurs. The large part of the area is covered by black cotton soil, which is important for agriculture purpose. Litho- stratigraphically, present study area comes under Mahabaleshwar formation of Upper Deccan Traps in India [18]. At the height above 880 mts columnar joints in Basalt (Fig. 3) are observed all over the hill. The hill top is covered by laterite of Pleistocene age. It is formed by in situ chemical weathering of columnar basalt above $935 \mathrm{~m}$. above msl. Laterite is red or brown coloured rock mainly composed of iron oxides and clay, formed due to residual product of weathering in tropical and sub-tropical area.

\section{Geomorphology}

Geomorphology is defined as the systematic description and analysis of landscapes and the processes that changed them [19]. In present study area is classified into eight different morpho units (Landforms) viz., Younger alluvial plain, pediplain, pediment, valley fill sediments, highly dissected plateau, mesa, denudational hill, lateritic plateau and pass (Fig. 4), on the basis of physiographic characteristics, morphological features, relief, slope, drainage density, and lithology. Using Resoursat-1 IRS LISS-III satellite image, SRTM DEM arc $30 \mathrm{~m}$ resolution, topographic map, profile study, and visual field studies were are also made in arriving at the classification and in delineating the boundaries of these morpho units.

Younger Alluvial Plain: Sedimentary deposition of extensive alluvial plain occurs in northern and southern part of the hill. In north is Varna river plain and in south is Panchaganga river plain. Both the river plains mostly consist of gravels, sand, silt and clay material. The total area covered by younger alluvial plain is $7.40 \mathrm{sq}$. $\mathrm{km}$. i.e. $1.53 \%$ of the total area.

Pediplain: Pediplain area found in parallel to the course of river channel. This area is gently sloping; highly weathered basaltic rock consists of undulating topography and thick soil cover mostly covered by agricultural part. Groundwater condition is very good in this area. The elevation of this geomorphic unit is $533 \mathrm{~m}$. to $570 \mathrm{~m}$. above msl and covers $214.86 \mathrm{sq}$. km. area i.e. $44.42 \%$ of the present study area. Drainage density $2.02 \mathrm{~km} / \mathrm{km}^{2}$, stream frequency is 2.31 streams $/ \mathrm{km}^{2}$ and textural ratio is $2.77 \mathrm{~km}^{-1}$, relative relief is low and gradient is low.

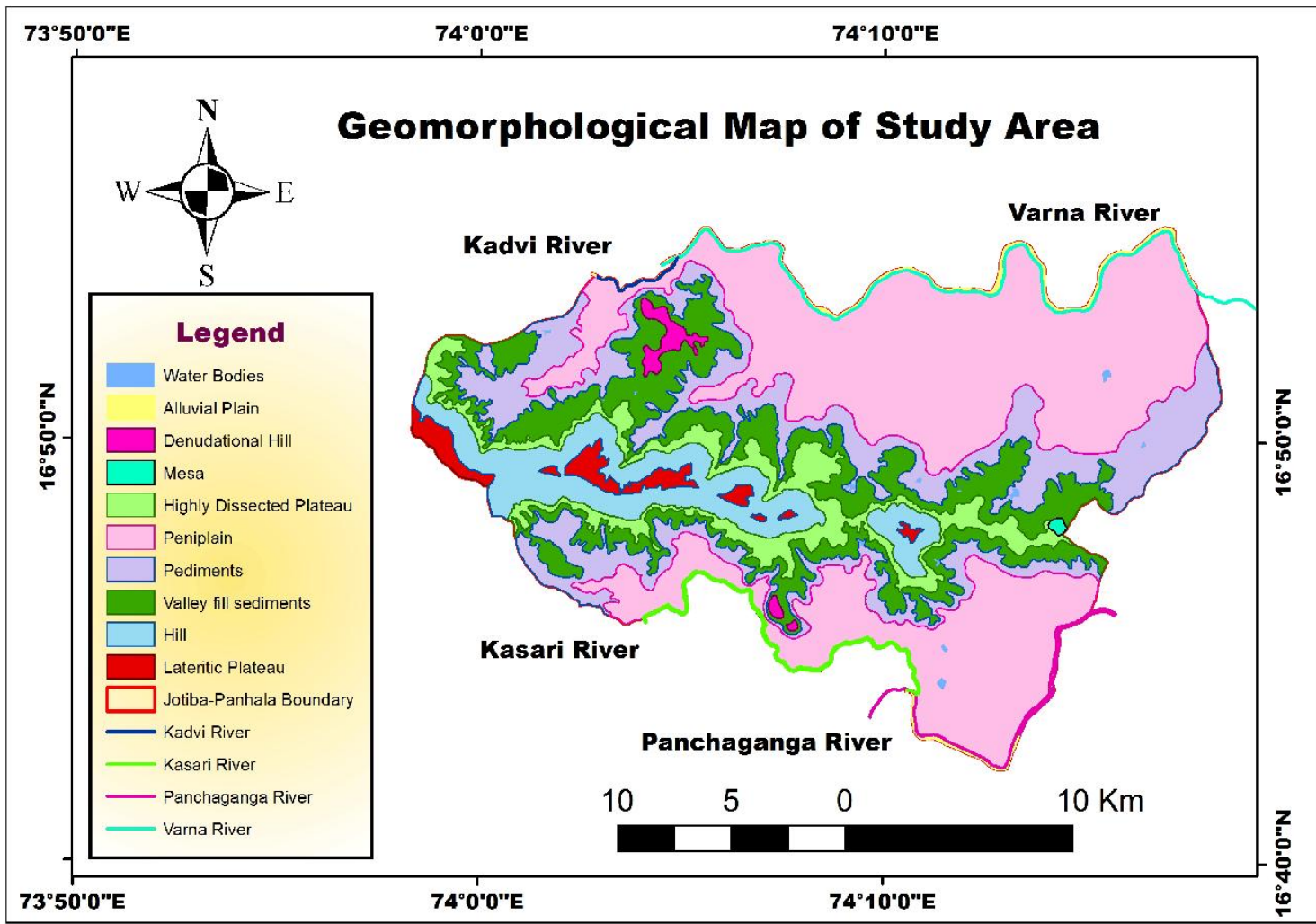

Fig. 4 Geomorphological Map of Jotiba- Panhala hill range area 
Application Of Remote Sensing, Geology And Geomorphological Studies For Mass Wasting Zone ..

Pediment: Pediment unit has bedrock portion of rock cut surface of mountain side. It occurs at the foot hill zone of highly dissected plateau. It covers an area of $90.48 \mathrm{sq} . \mathrm{km}$. i.e. $18.70 \%$ of the total area. The elevation of this geomorphic unit is $570 \mathrm{~m}$. to $700 \mathrm{~m}$. above msl. The drainage density is $3.12 \mathrm{~km} / \mathrm{km}^{2}$, stream frequency is 7.64 streams $/ \mathrm{km}^{2}$, textural ratio is $1.92 \mathrm{~km}^{-1}$ relative relief is low and gradient is moderate to gentle.

Valley fills deposits: This area found in northern and southern part of the hill part. The material in these surface, consists mainly of weathered product of the surrounding basalt rock, mostly comprise moderately thick gravels, pebbles, sand and silt. The elevation of this geomorphic unit is $620 \mathrm{~m}$. to $700 \mathrm{~m}$. above msl and covers $82.40 \mathrm{sq} . \mathrm{km}$. area i.e. $17.03 \%$ of the total study area. The drainage density is $3.22 \mathrm{~km} / \mathrm{km}^{2}$, stream frequency is 9.88 streams $/ \mathrm{km}^{2}$, textural ratio is $2.19 \mathrm{~km}^{-1}$, relative relief is low and gradient is moderate.

Highly dissected Plateau: The land of this unit is several dissected by the streams of sub-basin giving rise to a terrain consists of flat topped ridges and steep scarps occur all around the hill terrain. The unconsolidated material rolling down from hill, it settles over the gently sloping surface of the highly dissected plateau area. In last rainy session has been found that, because of heavy rainfall this unconsolidated material fill up with water and loose there strength. Due to high content of water small mass movements are occurs in this area. Some mass wasting movements are observed in last rainy season at Jotiba-Kerli road section slumping movement of weathered lava flow is occurs due to heavy rainfall (Fig. 5).

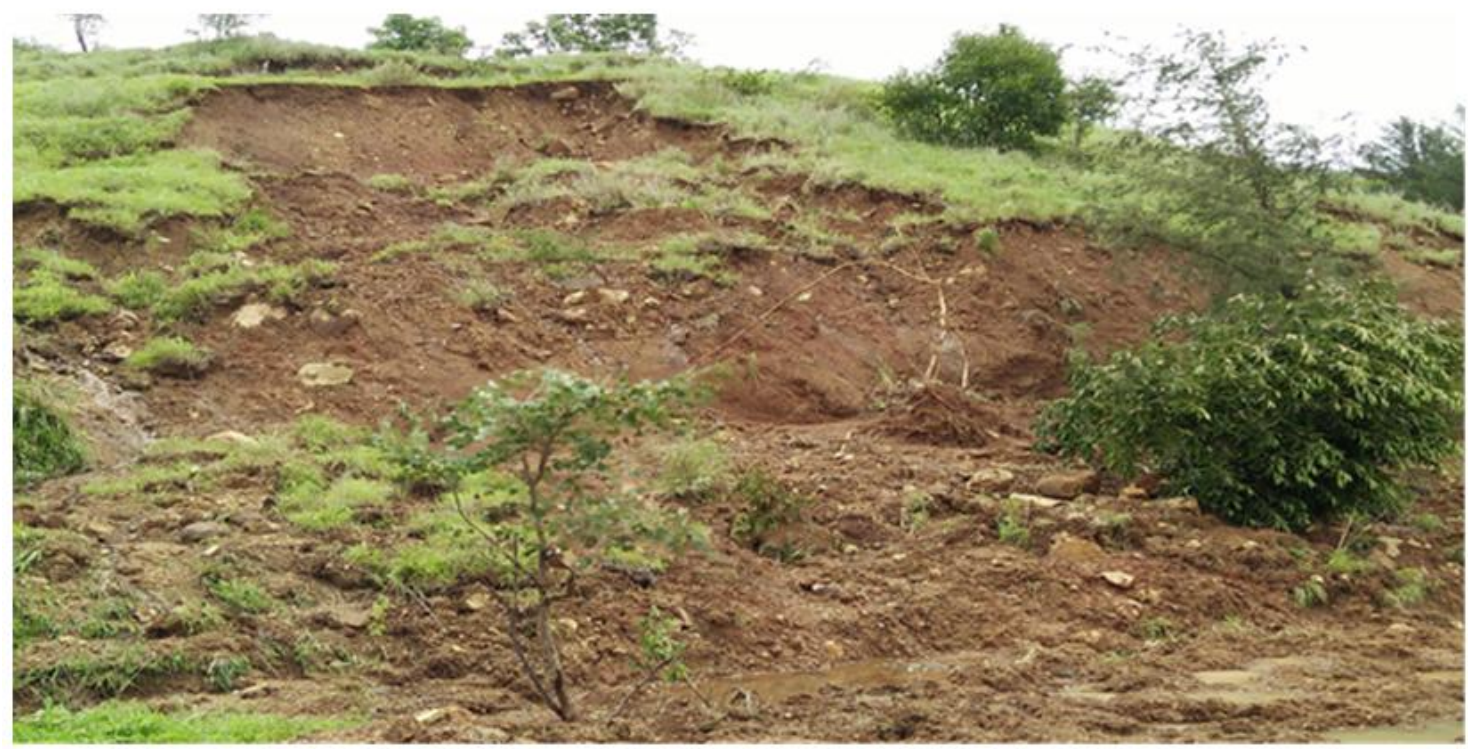

Fig. 5 Jotiba-Kerli road section slumping movement of weathered lava flow

The elevation of this geomorphic unit is $700 \mathrm{~m}$.to $740 \mathrm{~m}$. above msl and covers $33.50 \mathrm{sq}$. km. area i.e. $6.93 \%$ of the present study area. The drainage density is $2.87 \mathrm{~km} / \mathrm{km}^{2}$, stream frequency is $11.37 \mathrm{streams} / \mathrm{km}$, textural ratio is $2.10 \mathrm{~km}^{-1}$, relative relief is high and gradient is moderate to steep. On the basis of field characters and morphometric characteristics of this geomorphic unit it is found that it is a part of land slide prone zone.

Denudational Hill: Hill is isolated, low relief and generally barren type of rocky area. In present research area, the hill portion is consists of highly resistant columnar basaltic rock formations (fig. 3). This geomorphic unit occurs at elevation $740 \mathrm{~m}$. to $935 \mathrm{~m}$. above msl and covers $44.93 \mathrm{sq}$. $\mathrm{km}$. area i.e. $9.2 \%$ of the present study area. Drainage density $3.12 \mathrm{~km} / \mathrm{km}^{2}$, stream frequency is 8.41 streams $/ \mathrm{km}^{2}$, textural ratio is $3.14 \mathrm{~km}^{-1}$, relative relief is high and gradient is steep. During field work there are two mass wasting movement are occurs one is nearer to Somwar peth Panhala (Fig.6) due to heavy rainfall road are subsided nearly 4 feet downward.

In another location near Panhala hill (Fig.7) columnar basaltic blocks are rolling down due to gravity. It is debris sliding occurs in geological past. Similar type of sliding occurs near main road, Waghabil-Panhala village road section every rainy season. It is found that this area also susceptible for landslide.

Mesa: It is a highly resistant rock landmass of medium sized small hill. In present study Mesa is observed near Sadle- Madale village settle in Jotiba hill area. The maximum elevation of this area is $720 \mathrm{~m}$. 
Application Of Remote Sensing, Geology And Geomorphological Studies For Mass Wasting Zone ..

Lateritic Plateau: Laterite rock is formed due to insitu chemical weathering of pre-existing rock formation in tropical and sub-tropical climatic condition. In present study, Lateritic plateau locally named as Masai Plateau, occurs above $935 \mathrm{~m}$. elevation above msl. It covers an area of about $9.78 \mathrm{Sq}$. $\mathrm{km}$. i.e. $2.02 \%$ of the total study area. The soil cover is reddish to dark brown in colour, mostly dry land without vegetation.

Pass: Sudden drop in elevation in between two hills is known as pass. It indicates that an area is highly resistant to erosion.

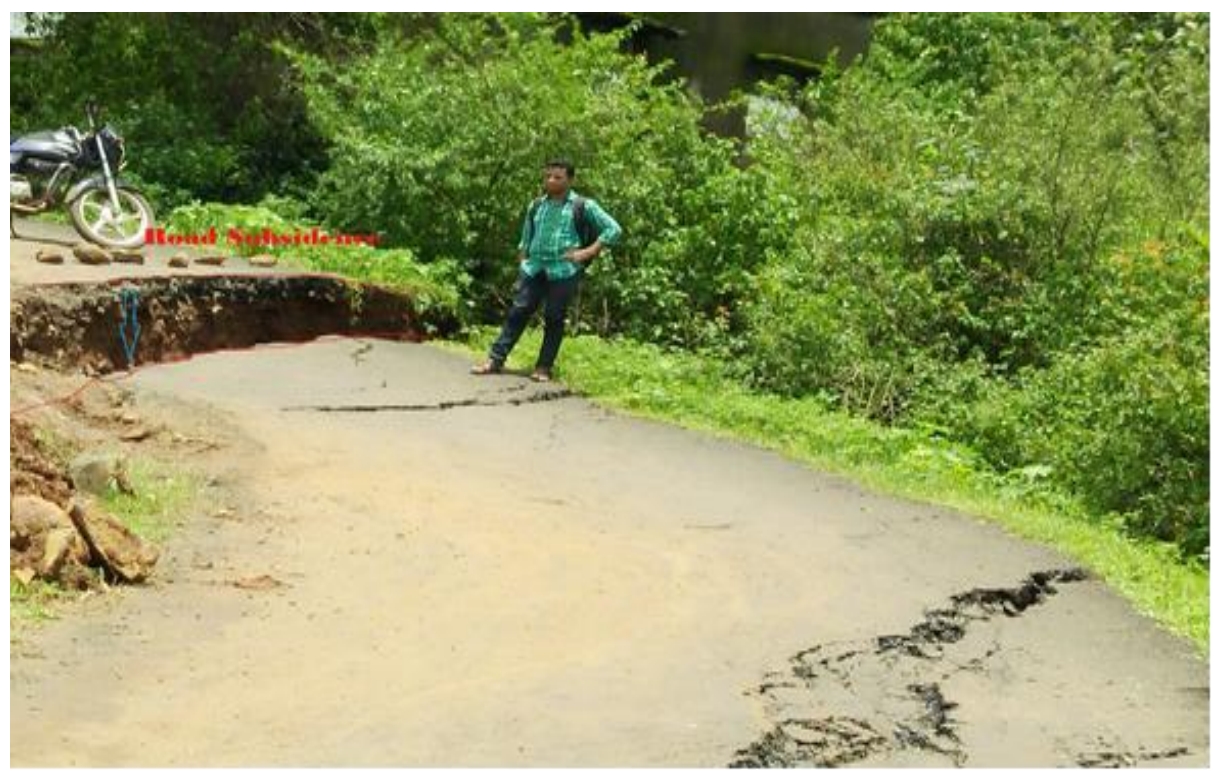

Fig. 6 Slumping movement occurs near Somwarpeth Panhala hill.

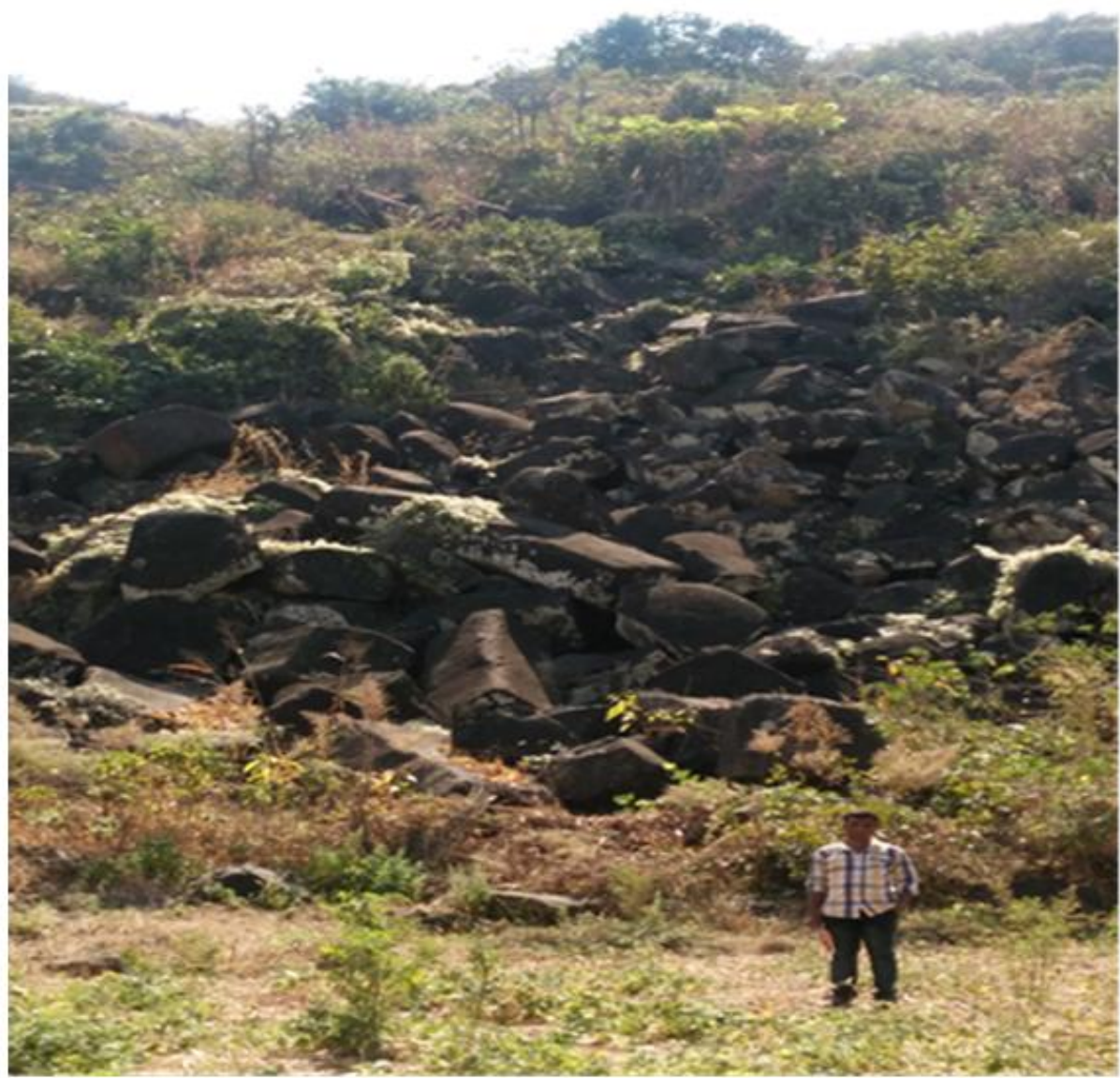

Fig. 7 Columnar blocks (Debris) sliding observe in Panhala hill range are. 


\section{Land Use/ Land Cover}

Land use and land cover analysis (Fig. 8) is carried out with the help of Resoursat-1 IRS LISS-III satellite image. It is downloading from Bhuvan and then its bands are stack processed under by ERDAS 2014 software. Land use/ land cover it is anthropogenic activities carried out on land surface. It's related to the geomorphology of the area, geology, hydrology and climate also. In present study, five units are used for study the land use condition and its relationship with geology and geomorphology of the area. These units are agricultural land, forest land, settlement, barren land and water bodies. (Table 1)

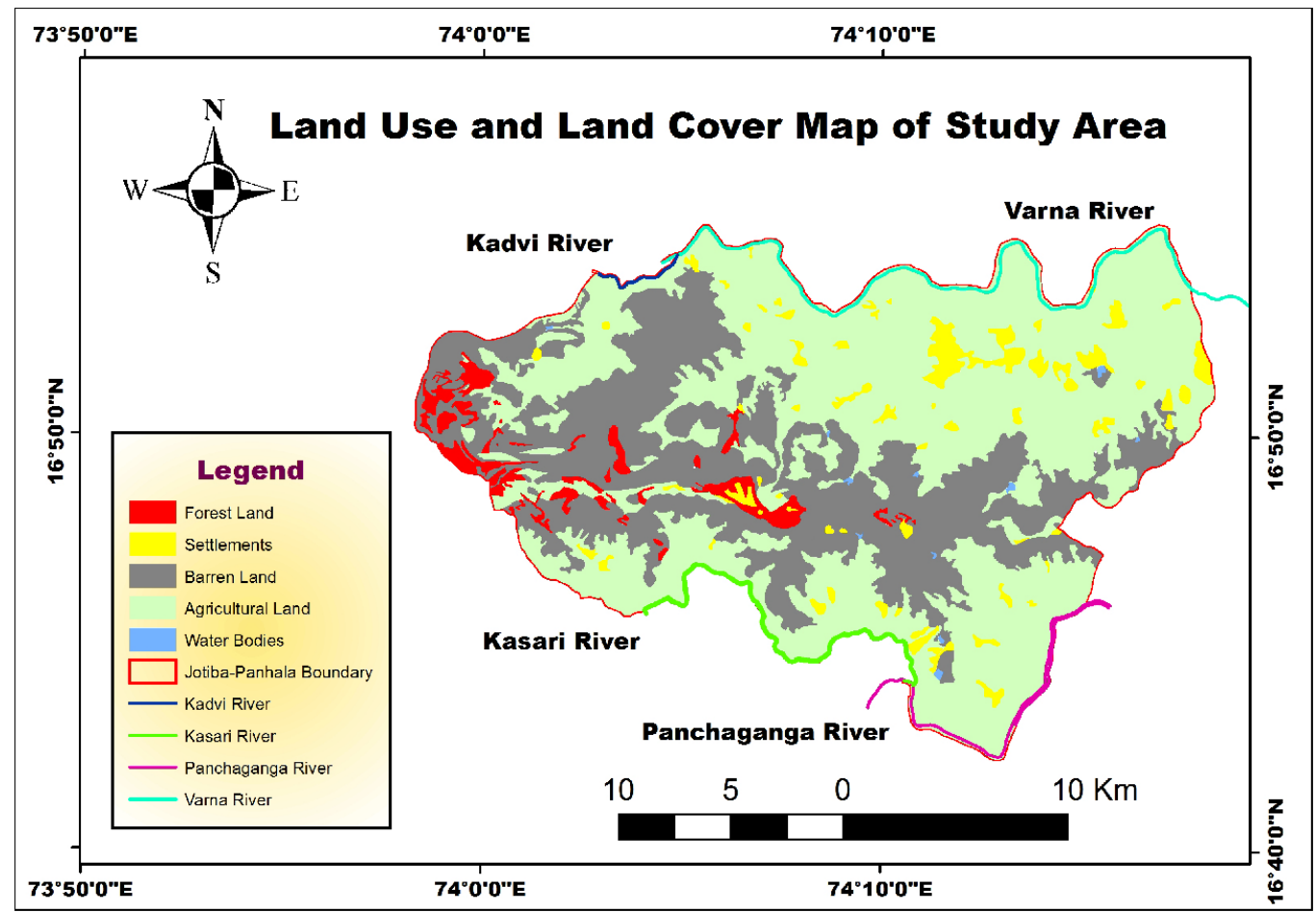

Fig. 8 Land use/ land cover map of Jotiba- Panhala hill range area

Table.1 Land use/ Land cover analysis of study area

\begin{tabular}{|c|c|c|}
\hline Type of Land & Covered Area & Description \\
\hline Agricultural Land & $\begin{array}{l}\text { 282.4 Sq.km i.e. } \\
58.4 \%\end{array}$ & $\begin{array}{l}\text { Most of agricultural area covered with Sugarcane along the rivers. } \\
\text { Seasonal crop area occurs in highly dissected plateau area }\end{array}$ \\
\hline Forest Land & $\begin{array}{l}15.7 \mathrm{Sq} . \mathrm{km} \\
\text { i.e. } 3.2 \%\end{array}$ & $\begin{array}{l}\text { Western part of the hill area is covered by thick forest; some other } \\
\text { area like foot hill of hill is also covered by dense forest. }\end{array}$ \\
\hline Settlement & $\begin{array}{l}\text { 20.9Sq.km } \\
\text { i.e. } 4.3 \%\end{array}$ & $\begin{array}{c}\text { It occurs mostly near river channels, Some settlement also seen in } \\
\text { highly dissected plateau area. }\end{array}$ \\
\hline Barren Land & $\begin{array}{l}\text { 164.7 Sq.km. i.e. } \\
33.17 \%\end{array}$ & $\begin{array}{l}\text { Steep sloping area, without soil cover are occurs both the sides of the } \\
\text { hill. Which indications of highly resistant rock formation }\end{array}$ \\
\hline Water Bodies & $\begin{array}{l}0.83 \text { Sq. km. i.e. } 0.17 \\
\% \text {. }\end{array}$ & Water bodies are occurs at the pediment area of the hill \\
\hline
\end{tabular}

\section{Slope Map}

Slope is simply means of inclination of the surface. It is formed due combination of several factors like geological structures, absolute and relative relief, climate, vegetation cover, drainage texture and drainage frequency etc. In present study area slope map is prepared with the help of SRTM DEM and ArcGIS 10.1 software. In slope map preparation SRTM DEM is first follow the fill analysis process form hydrological analysis tool and then slope map is repaired to use percentage in slope analysis tool from surface analysis tool. For find out Landslide susceptible zone in present research area is classified in to four units; $0-17$; 17-35; 35-52 and 52-88 (Fig. 9). The steep slope is observed all around the hill at 52-88 percentages. It is a columnar jointing Basaltic rock formation occurs all around the hill consists of nearly vertical slope (Fig. 3).

\section{Landslide Zonation Mapping}

In many regions of world especially in hilly terrain a temporary instable land mass (Soil, regolith, or talus deposits) has always been an actual problem. These masses may leave their original position abruptly or extremely slowly and start either a downgrade movement or vertical downward sinking thus give rise to be 
Application Of Remote Sensing, Geology And Geomorphological Studies For Mass Wasting Zone ..

difficult situation. Such superficial masses have been termed as landslides or landslips. The cause of landslide is heavy rainfall occurs in short time and others are earthquakes, road cutting, and construction of houses or agricultural part over the slope. The main objective of present research is to prepare landslide zonation mapping with the help of field evidences and remote sensing and GIS techniques for planning, development and risk management.

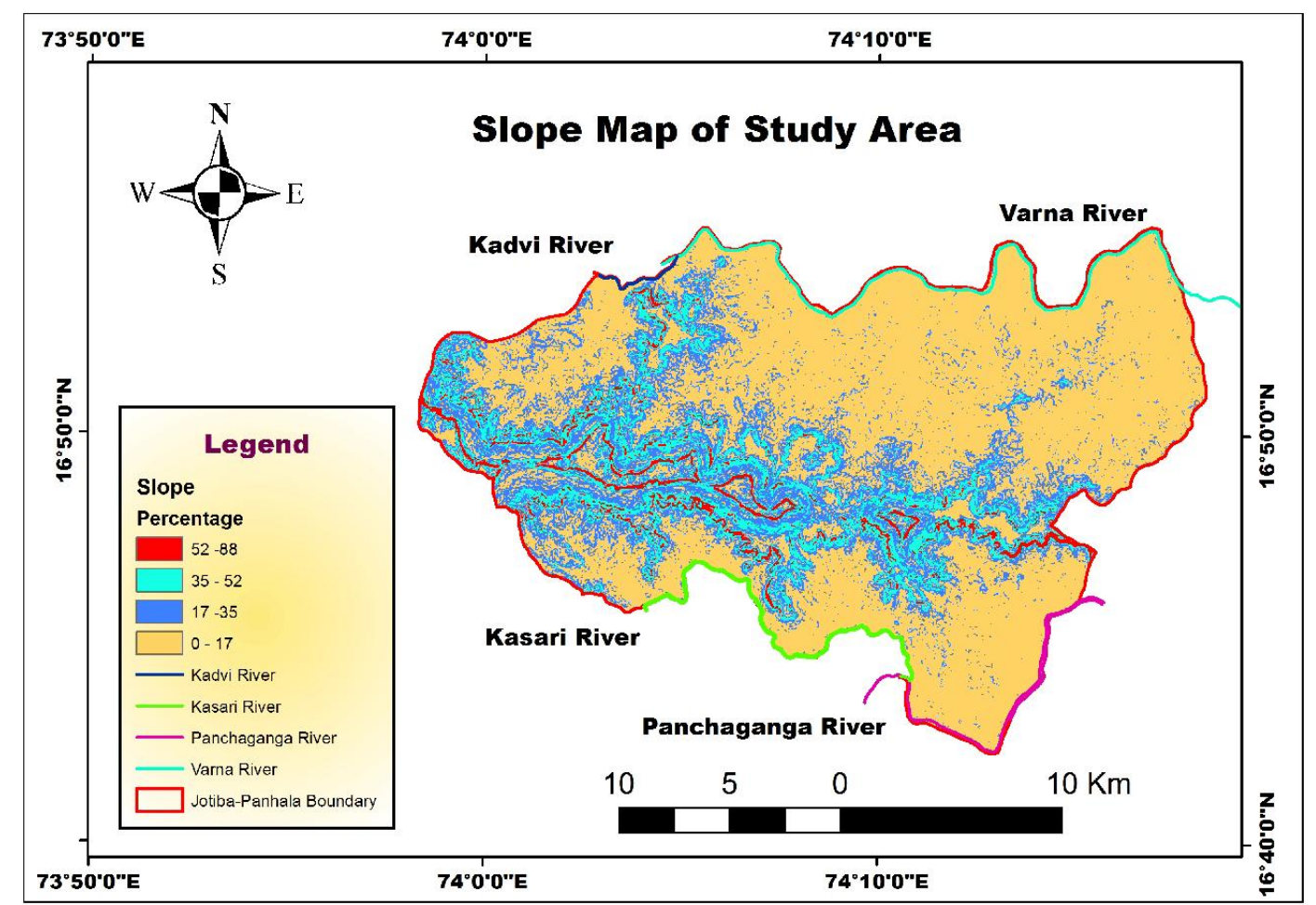

Fig. 9 Slope Map of Jotiba- Panhala hill range area

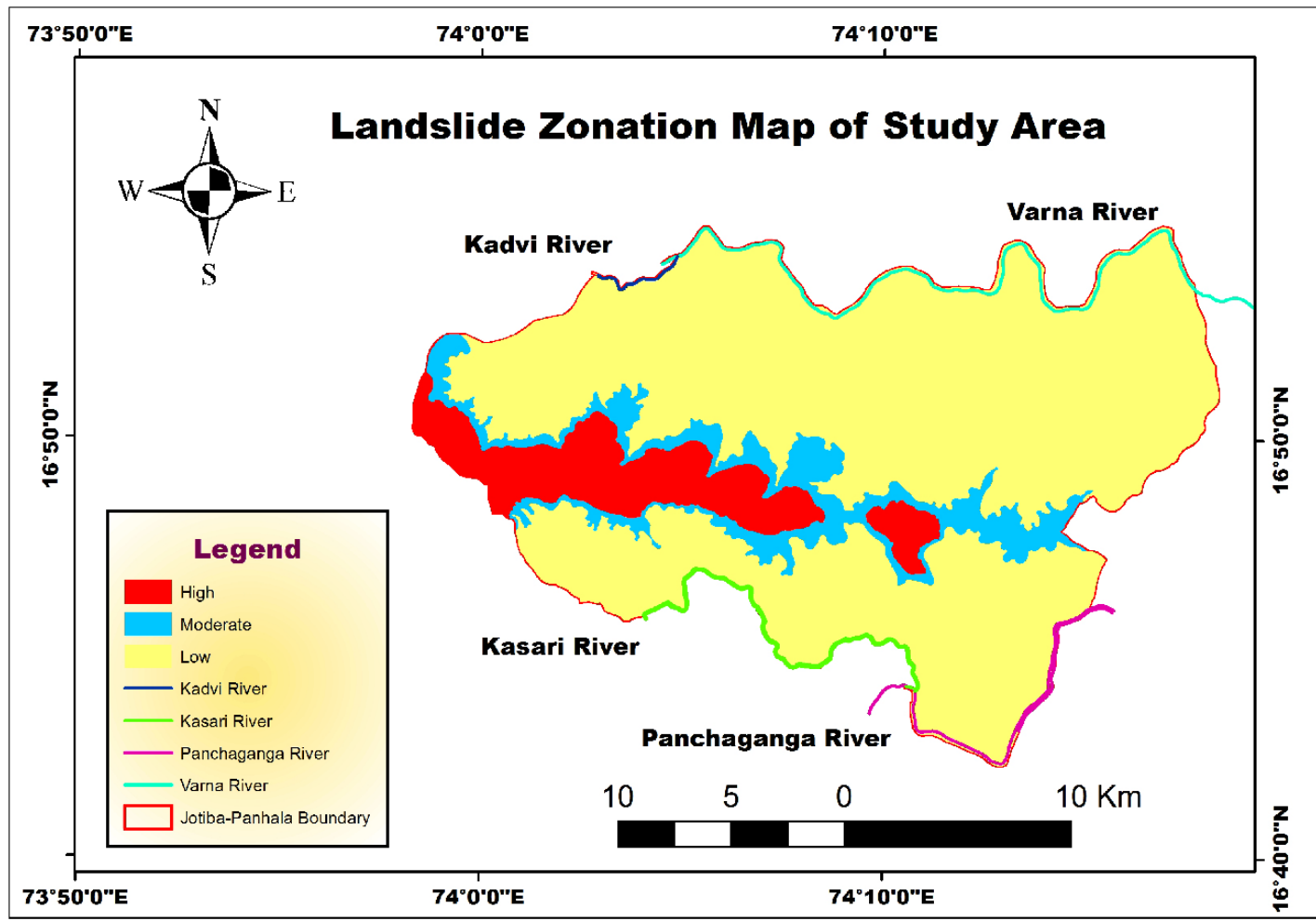

Fig. 10 Landslide Zonation Map of Jotiba- Panhala hill range area 
In present research landslide zonation mapping (Fig. 10) is done with the help of geomorphological parameters results, slope of the area and field evidences of mass wasting. The main cause of mass wasting in this area is heavy rainfall. Such types of mass wasting situations are preliminary indications of landslides. So for mitigation is concerned or minimize these type of situation some important things area adapted, such as small channel are constructed along the both sides of the road and railway lines, roads area constructed in gentle sloping area, plantation over soil, build-up of agricultural area over gentle slope, houses are construction over the plain area or hard rocky area etc.

\section{Conclusion}

The Remote Sensing and GIS techniques are given more accurate result for Landslide zonation mapping in present study. Geomorphological study observed that, highly dissected plateau and hill area is mostly prone for landslide. In present study area, steep slope is observed in south side of the hill as compared to north side. During South-West monsoon season, southern part of the hill area received more rainfall as compared to northern slope of the hill. After sometimes natural springs are originated due to heavy rainfall. These springs are originated in contact between two rock formations consists of vertical and horizontal jointing basaltic rocks. Most of the mass wasting movements are occurs, if spring are originating in to the hill portion consists of high relief and steep slope. Due to heavy rainfall and spring, soil or talus deposits (slides from the hill) and weathered rock material on a steep sloping surface underneath can become heavy with rain water and slides down due to its weight. Same situation are also found in most of the landslides in large scale.

\section{References}

[1]. Cruden D.M. A simple definition of Landslide. Bulletin of the International Association of Engineering Geology. 43, $1991,27-29$.

[2]. Vernes D.J. Slope movement type and processes, In Schuster RL and Krizek RL (Editor), Landslide; Analysis and Control, Special Report 176, Transportation Research Board national academy of Science Washington DC 1978,11-3.

[3]. Rai P.K., Mohan K. and Kumar V.K. Landslide Hazaed and its mapping using Remote sensing and GIS. Journal of Science research Banaras Hindu University Varanasi 58, 2014:1-13.

[4]. Metha R.L., Koli SR. and Koli V.R. Landslide Hazard Zonation Using Remote Sensing and GIS: A case study of Landslide prone area near Mahabaleshwar Maharashtra. International Journal of Engineering Research and General Science 3 (4), part-2 JulyAugust, 2015

[5]. Shaikh A.F., Gunjal P.K. and Chaple N.V. Report on Landslide in Malin Village in Pune. International Journal of Engineering Research and Research Technology 4(4), 2015.

[6]. Strahler AN. Quantitative analysis of watershed geomorphology. Trans. Am. Geophys. Union. 38, 1957, 913-920.

[7]. Babar Md and Kaplay R.D. Geomorphometric analysis of Purna River basin Parbhani District (Maharashtra). Indian Journal of Geomorphology 3 (1) 1999, 29-39.

[8]. Strahler A. N. Quantitative Geomorphology of Drainage Basin and Channel Network, Handbook of Applied Hydrology 1964.

[9]. Horton R.E. Drainage basin Characteristics, Trans. Amr. Geophy. Union, 13, 1932, 350-361.

[10]. Horton R.E. Erosional development of streams and their drainage basins: Hydrophysical approach to quantitative morphology. Geological Society of America Bulletin. 56, 1945, 275-370

[11]. Smith K. G. Standard for grading texture of erosional topography, Ame. J. Soc., 5 (298) 1950, 655-668

[12]. Sahastrabudhe, Y.S. Geology of part of Kolhapur District (47 L/1) Unpublished GSI Progress report 1953-54-55.

[13]. Punj, N.K. et.al. Geology of parts of Kolhapur District (47L/2), 1985-86.

[14]. Sabale, A. B. Report on detailed study of Precambrian rocks of Ratanagiri, Kolhapur and Sindhadurg District of Maharashtra, 199697.

[15]. Athavale H. and Natu S. R. Report on transverse mapping in toposheet 47L/1, 2 and 3 in Sangali and Kolhapur District, Maharashtra. 050/MAP/CR/MH/2004/2009

[16]. Gupte R.B. Engineering aspects of Deccan Trap Basalt. Maharashtra Publication work Journal 7(3-4), 1971, 7-20

[17]. Kulkarni S.R. Karmarkar B.N. and Gupte R.B. Variation in the nature of Deccan trap volcanicity of western Maharashtra in time and space. Memoir of the Geological Society of India 3, 1980, 143-152.

[18]. Godbole S.M., Rana R.S. Natu S.R. Lava stratigraphy of Deccan Basalt of Western Maharashtra. Gondwana Geol. Mag. Spl. Vol. 2 $1996,125-134$.

[19]. Bloom, A.L. Geomorphology. Prentice-Hall of India Private Ltd., New Delhi, 1979 pp.26-89. 